\title{
Ocular masquerade syndrome due to intraocular lymphoma - two forms of retinal pigment epithelium involvement: case reports
}

\author{
Síndromeocular mascarada devidolinfoma intra-ocular:relatodecasos
}

Miguel Hage Amaro ${ }^{1}$

Cristina Muccioli ${ }^{2}$

Mariza Toledo Abreu ${ }^{3}$
Department of Ophthalmology - UNIFESP - São Paulo (SP) - Brazil.

MD. Departament of Ophthalmology. Universidade Federal de São Paulo - UNIFESP - São Paulo (SP) Brazil.

${ }^{2}$ Professor of Ophthalmology. Departament of Ophthalmology - UNIFESP - São Paulo (SP) - Brazil.

3 Professor of Ophthalmology. Vice-coordenator of Posgraduation in Departament of Ophthalmology UNIFESP - São Paulo (SP) - Brazil.

Corresponding Author: Miguel Hage Amaro. Rua Quintino Bocaiuva, 516 - Belém (PA) - Brazil

CEP 66053-240

E-mail: amaro@amazon.com.br

Recebido para publicação em 16.02.2006

Versão revisada recebida em 24.10.2006 Aprovação em 30.10.2006

Nota Editorial: Depois de concluída a análise do artigo sob sigilo editorial e com a anuência da Dra. Zélia Maria da Silva Corrêa sobre a divulgação de seu nome como revisora, agradecemos sua participação neste processo.

\begin{tabular}{|l|}
\hline ABSTRACT \\
\hline Ocular masquerade syndrome was diagnosted in two patients with chronic \\
uveitis. The patients presented non-Hodgkin's lymphoma as the final \\
diagnosis two forms of intraocular retinal pigment epithelium involvement \\
was seen. One case was flecks of the retinal pigment epithelium and another \\
case was a solid retinal pigment epithelium detachment. These unusual \\
presentations of non-Hodgkin's lymphoma is an alert to all involved in \\
lymphoma care.
\end{tabular}

Keywords: Lymphoma, non-Hodgkin ; Uveitis; Syndrome; Central nervous system; Fluorescein angiography/methods; Pigment epithelium of eye; Case reports [publication type]

\section{INTRODUCTION}

Ocular masquerade syndrome (OMS) is a group of diseases that occurs with ocular inflammation and is misdiagnosed as a chronic uveitis ${ }^{(1)}$.

It was first described as a chronic case of conjunctivitis masquerading conjunctival carcinoma ${ }^{(2)}$. In the same year, a diffuse epibulbar squamous cell epithelioma masquerade case was reported ${ }^{(3)}$.

In fact, OMS is the most commonly used term to describe diseases simulating a chronic uveitis ${ }^{(1)}$.

The causes of OMS may be benign or malignant disorders ${ }^{(1)}$.

Nonmalignant diseases include: intraocular foreign body, retinal detachment, pigment dispersion syndrome, postoperative infections, postvaccination disorders and drug reaction (rifabutin, didanoside).

Malignant diseases include: intraocular lymphomas (non-Hodgkin's lymphoma of central nervous system, systemic non-Hodgkin's lymphoma metastatic to the eye, Hodgkin's lymphoma, leukemia, carcinoma metastastic to the eye (lung, renal, breast) uveal melanoma, childhood malignancies (retinoblastoma, leukemia, meduloepithelioma, juvenile xanthogranuloma), paraneoplastic syndromes (cancer-associated retinopathy, melanoma-associated retinopathy, bilateral diffuse uveal melanocytic proliferation).

Gass classification ${ }^{(4)}$ of lymphoma is subdivided as follows: 1) Hodgkin's lymphoma; 2) large-cell non-Hodgkin's lymphoma; 3) neoplastic angioendotheliomatosis; 4) lymphocytic lymphoma; 5) Burkitt's lymphoma; 6) mycosis fungoides; 7) multiple myeloma; 8) lymphoid granulomatosis.

Large-cell non-Hodgkin's lymphoma has two forms of intraocular involvement ${ }^{(5)}$. One form originates from outside the central nervous system with metastasis to the eye and the other form arises from within the central nervous system and eye and is usually referred to as primary central nervous system lymphoma $^{(6)}$. 
Primary central nervous system lymphoma initially involves the eye. The incidence of this form is $0.3 \%$ per 100,000 person-years in the immunocompetent population and 4 to 5 per 1,000 person-years among AIDS patients ${ }^{(7-8)}$. The incidence has tripled over the past 2 decades ${ }^{(9)}$. It accounted for approximately 1,000 people per year in the United States ${ }^{(10)}$. Ocular involvement at the time of the diagnosis is $15 \%$ to $25 \%$. An estimated 100 new cases occurred in the United States over the past 3 years ${ }^{(11)}$. The disease affects an older population (the median age is in the 50 to 60 -year). There is a slight male predominance ${ }^{(12)}$. Ocular involvement may precede the disease in the brain, spinal cord and leptomeninges ${ }^{(6,11)}$.

Two thirds of the patients had the undiagnosed disease in the central nervous system at the time the ocular diagnosis was established ${ }^{(13)}$. The time between the onset of ocular symptoms and central nervous system symptoms varied from 7 to 108 months (mean 29 months) $)^{(13)}$.

It also appears that immunosuppression appears to be a risk factor for the development of ocular lymphoma ${ }^{(14-15)}$.

In a study ${ }^{(13)}$, the disease appeared typically as an intermediate or posterior uveitis. The common sites of ocular involvement are the vitreous, retina, retinal pigment epithelium (RPE) and the optic nerve head or any combination of these sites ${ }^{(4)}$.

Cranial magnetic resonance imaging and a lumbar puncture should be performed in all patients suspected of having intraocular lymphoma and, if no malignant cells are found, a culture medium tissue from a three-port pars plana vitrectomy is made ${ }^{(1,4)}$. The vitreous specimens were processed as previously described ${ }^{(16-17)}$.

The intravitreal cytokine level can be useful in the diagnosis of intraocular lymphoma ${ }^{(18)}$. Interleukin-10 can be produced by lymphoma cells and levels of interleukin-10 are elevated in both the serum and vitreous of patients with intraocular lymphoma ${ }^{(18)}$.

Treatment of primary central nervous system non-Hodgkin's lymphoma is controversial ${ }^{(5)}$. In patients with the disease limited to the eye, the treatment can be limited to the eye or can also be applied prophylactically to the central nervous system. In a series of cases ${ }^{(19)}, 10$ of 11 patients with lymphoma limited to the eyes at initial diagnosis later developed the disease in the central nervous system.

Isolated radiation therapy is currently less used as single therapy ${ }^{(20)}$. Its association with systemic chemotherapy is a good option $^{(21-22)}$. Systemic chemotherapy ${ }^{(23-24)}$, intrathecal ${ }^{(25)}$ and intravitreal methotrexate ${ }^{(26-27)}$, are also used in selected cases.

The objective of this paper is to present two cases of patients with intraocular non-Hodgkin's lymphoma, each showing a different form of retinal pigment epithelium involvement.

\section{METHODS}

We evaluated two patients with idiopathic uveitis preceding non-Hodgkin's lymphoma. One patient presented a systemic form of large-cell non-Hodgkin's lymphoma (case 1) and the other showed primary central nervous system lymphoma (case 2).

\section{CASE REPORTS}

\section{Case 1}

A 56-year-old Caucasian woman noted blurring, dimness of vision, and floaters in the right eye. Her visual acuity was $20 / 80$ in the right eye and 20/25 in the left eye. There were paracentral scotomas in the right eye on Amsler grid testing. The anterior segment was normal in both eyes. The intraocular pressure was $16 \mathrm{mmHg}$ in the right eye end $12 \mathrm{mmHg}$ in the left eye. There were $2+$ vitreous cells, in the right eye. In the equatorial and posterior fundus we noted grey-white sub-RPE flecks in the right eye (Figure 1).

The left fundus was normal. Fluorescein angiography showed a pattern of early nonfluorescence on a background of hyperfluorescence on the posterior and equatorial fundus corresponding to the retinal flecks; there was evidence of some staining of the level of RPE in some areas of the fundus (Figure 2).

Eight months after the intraocular diagnosis the patient developed systemic lymphoma with enlargement of lymph nodes on the neck in addition to a depressed lesion at the base of the neck, lymphadenophaty of the right axilla and supraclavicular areas. Computed tomography revealed peritoneal masses. A diagnosis of systemic lymphoma was established by biopsy. One year after the initial ocular findings the patient died of central nervous system metastasis.

\section{Case 2}

A 65-year-old Caucasian female complained of blurred vision and dimness of vision in the right eye. Her visual acuity was $20 / 400$ in the right eye and 20/25 in the left eye. The anterior

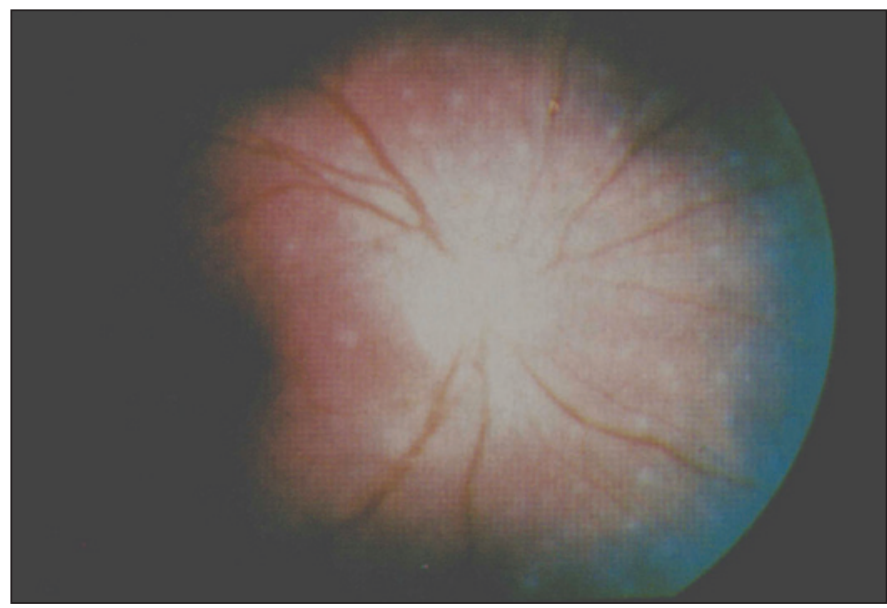

Figure 1 - Multiple retinal pigment epithelium infiltrates of the lymphoma tumors 
segment was normal in both eyes. The intraocular pressure was $12 \mathrm{mmHg}$ in the right eye end $14 \mathrm{mmHg}$ in the left eye. There were $2+$ vitreous cells in the right eye. Ocular fundus examination revealed multiple yellowish-tan, variable-sized and-shaped detachments of the retinal pigment epithelium widely scattered throughout in the posterior pole and the macula region on the right eye

The left eye ocular fundus was normal. Fluorescein angiography (FA) of the patient's right eye revealed first show blocking early because of the mass of tumor cells beneath the

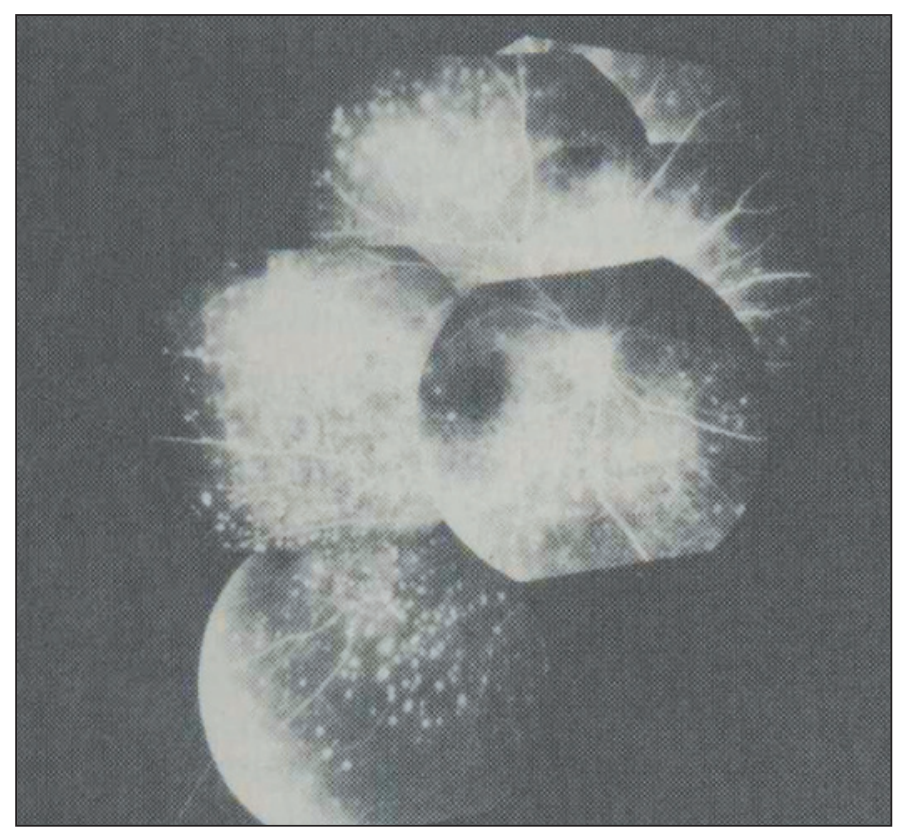

Figure 2 - Hyperfluorescence of the multiple lesions in the late phases on fluorescein angiography

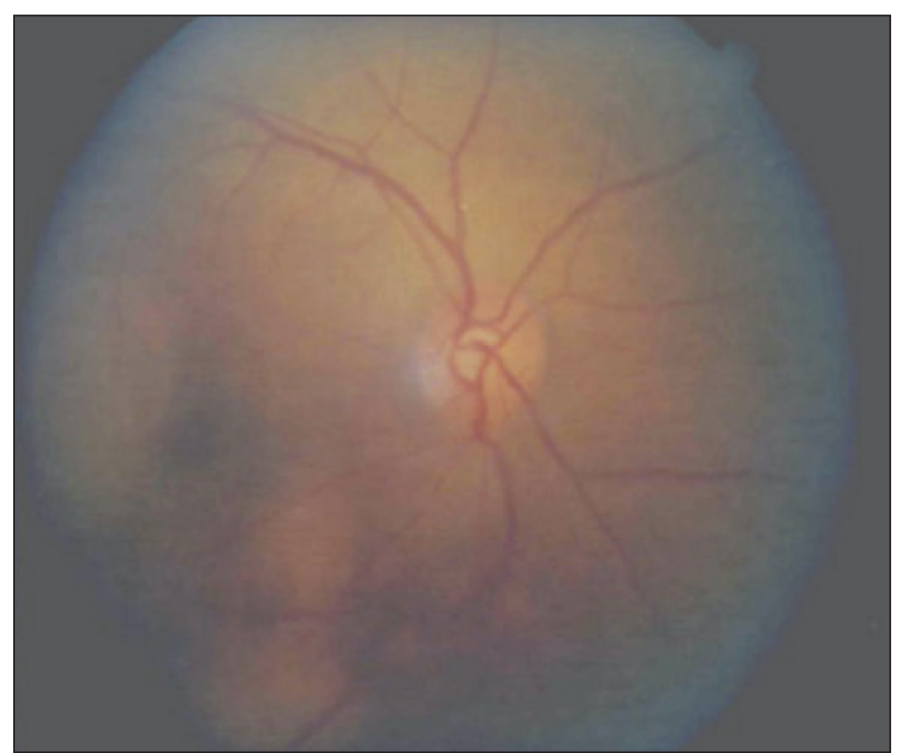

Figure 3 - Multiple solid retinal pigment epithelium detachments in the posterior pole
RPE. The blocking is especially apparent in the macula where the mass appears to be thickest (Figure 4).

The blocking is of the choroidal fluorescence and because the cells lie in front of the choroid. Then the FA shows late leakage from breakdown of the outer blood retinal barrier, again due to the infiltration of the tumor cells (Figure 5).

Fluorescein angiography of the left eye was normal.

Ultrasonography of the right eye shows a questionable thickening of the mass beneath the RPE (Figure 6)

Ten months after the ocular diagnosis the patient was diagnosed as having central nervous system lymphoma with lumbar puncture revealing lymphoid cells.

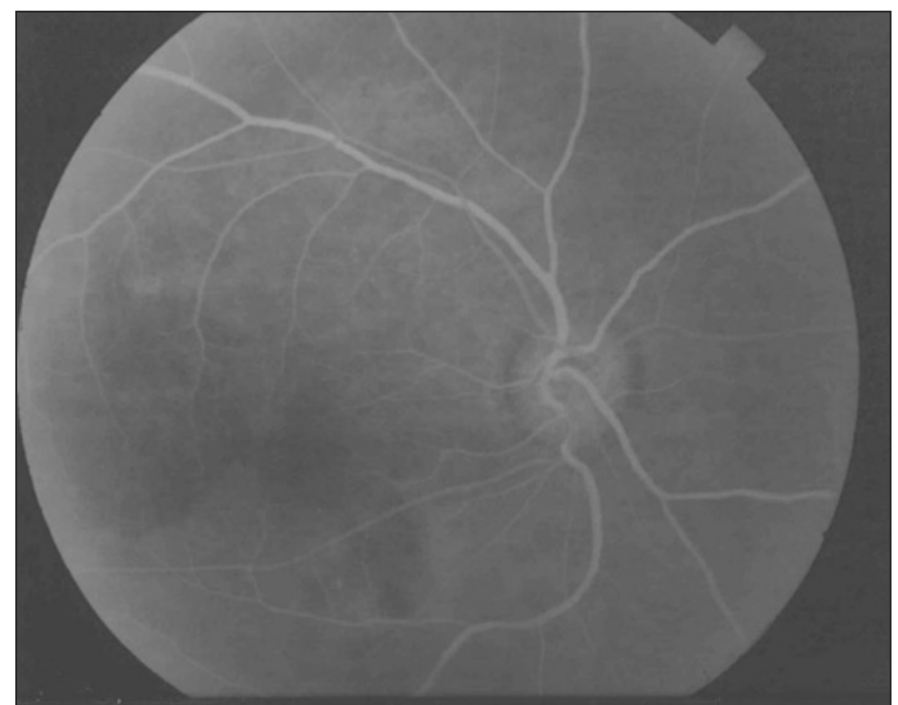

Figure 4 - Fluorescein angiography first show blocking early because of the mass of tumor cells beneath the RPE

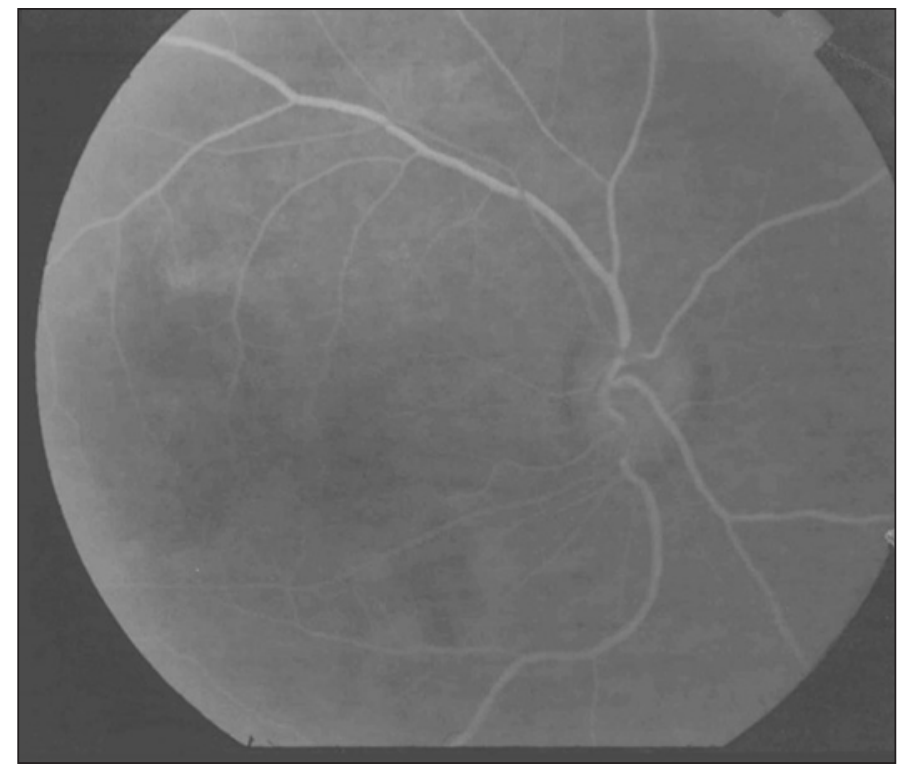

Figure 5 - Fluorescein angiography shows late leakage from breakdown of the outer blood retinal barrier due to the infiltration of the tumor cells 


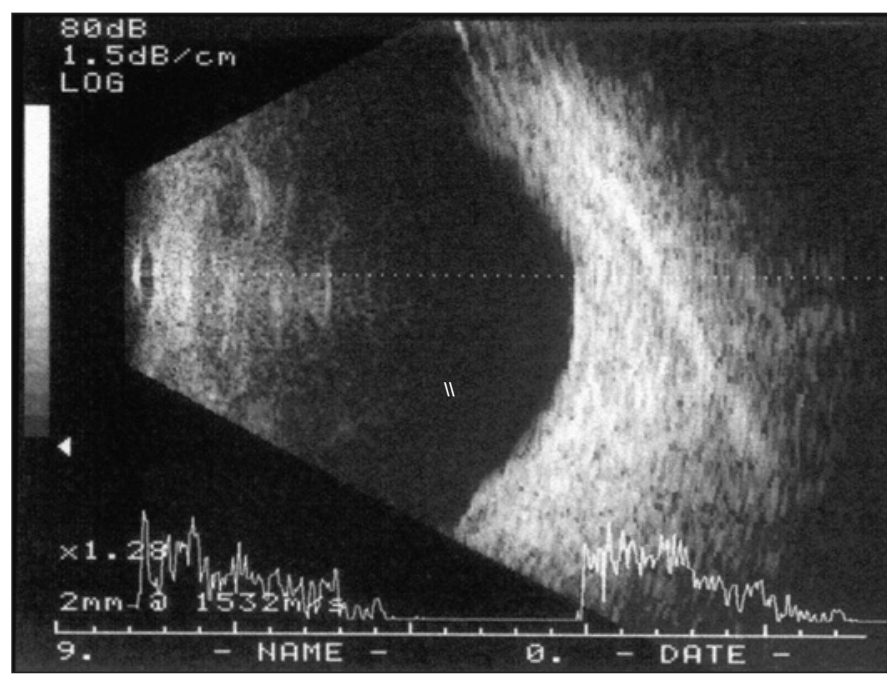

Figure 6 - Ultrasonography shows a questionable thickening of the mass beneath the RPE

\section{DISCUSSION}

Ocular masquerade syndrome was found in 5\% of all of the uveitis cases ${ }^{(28)}$. Intraocular malignancy corresponded to $2.5 \%$ of the uveitis cases and $48 \%$ of the uveitis masquerade syndrome, while intraocular lymphoma corresponded to $32.5 \%$ of the malignancies causing masquerade syndrome.

The ocular-central nervous system form of large-cell nonHodgkin's lymphoma is more frequent than the systemic manifestation. The systemic form corresponds to $25 \%$ of the patients with large-cell non-Hodgkin's lymphoma ${ }^{(4)}$.

The lymphoma cells in the ocular-central nervous system form of the disease appear to arise primarily in the vitreous and in the sub-RPE space and only secondarily extend to the retina and choroid ${ }^{(4,29)}$. Patients show a wide variety of pictures that may simulate many ocular disorders. They are usually in the sixth to seventh decade of life ${ }^{(4,29)}$.

Young adults and children are occasionally affected ${ }^{(30)}$.

The ocular-CNS form of large-cell lymphoma most frequently masquerades as posterior uveitis in patients complaining of floaters caused by the vitreous infiltration with lymphomatous and inflammatory cells.

Most of the patients develop multiple fundus lesions, which initially may be relatively flat and appear similar to multifocal choroiditis or multiple evanescent white dot syndrome, but typically enlarge to form solitary, sharply defined, blister-like yellowish sub-RPE tumors that are usually sufficiently characteristic to allow an accurate diagnosis ${ }^{(4,29,31)}$. The fine speckling of pigment on the surface of the amelanotic subretinal mounds is the biomicroscopic clue to the sub-RPE locations of the tumors, which may be confluent and massive in size. Other descriptions include white lesion tumors that may simulate acute retinitis ${ }^{(32)}$ branch artery occlusion by infiltration of the major retinal artery ${ }^{(33)}$, hemorrhagic infarction of the retina simulating that seen in acute retinal necro- $\operatorname{sis}^{(34)}$, lymphomatous infiltration of the retrobulbar portion of the optic nerve simulating retrobulbar neuritis or infiltration of the optic nerve head simulating papilitis ${ }^{(35-38)}$, iridocyclitis and secondary glaucoma ${ }^{(4)}$.

In some patients there is a remarkable tendency of subpigment epithelial lesions to resolve spontaneously. When this occurs, early multifocal small scars simulating those in the presumed ocular histoplamosis syndrome appear ${ }^{(39)}$.

When large lesions resolve, large foci of geographic atrophy of the pigment epithelium may simulate that seen in degenerative or postinflammatory disorders. It was published ${ }^{(4)}$, that when present, the multiple solid RPE masses are very suggestive of large-cell lymphoma. It so happened in our case 2 when the patient presented multiple RPE solid detachment predating central nervous system symptom involvement.

In the systemic form of large-cell non-Hodgkin's lymphoma the eye and brain are infrequently affected. When the eye is involved, the lymphomatous infiltration occurs primarily in the cilliary body and choroid. Choroid or sub-RPE infiltration may produce a peculiar fundus picture composed of a reticular pattern of yellowish-white flecks simulating fundus flavimaculatus and serous detachment of the retina in the macular area; this fundus picture may be confined only to the eye or may be the presenting manifestation of the systemic lymphoma ${ }^{(4)}$.

Our case 1 presented peculiar yellowish-white retinal pigment epithelium flecks in the systemic large-cell non-Hodgkin's lymphoma. Eight months after the intraocular diagnosis the patient developed systemic lymphoma with enlargement of lymph nodes in the neck in addition to a depressed lesion at the base of the neck. The patient subsequently died from complications of central nervous system involvement.

One patient was observed to have a systemic lymphoma with this peculiar fundus picture in one eye and with multiple large RPE tumors in his opposite eye typical of that in the ocular-CNS form of large-cell non-Hodgkin's lymphoma ${ }^{(4)}$. This observation suggests that there is some overlap in the two forms of large-cell non-Hodgkin's lymphoma ${ }^{(4,20)}$.

A group of researchers from the National Eye Institute in the United States ${ }^{(40)}$ published different fluorescein angiographic patterns confirmed by histopathologic analysis. The most common pattern were disturbances at the RPE level occurring in 31 eyes from 17 patients with primary intraocular lymphoma. These disturbances of the RPE were: granularity $(61 \%)$; blockage (55\%) and late staining $(45 \%)$, more than one could be found in the same patient. Our cases had neither characteristics. In this research RPE detachment and punctate hyperfluorescent lesions were less common. These clinical pictures should be recognized so that the diagnosis of lymphoma may be made as early as possible.

A practical clinical classification of intraocular lymphoid tumors and infiltrations has been described ${ }^{(41)}$ and further studies will be necessary to show us if such classification will lead to an appropriate baseline staging evaluation and improve our treatment of diseases of this category. 


\section{ACKNOWLEGMENTS}

To Professor J. Donald M. Gass, MD of Vanderbilt University for analyzing case 1 and to Professor James Folk, MD of Iowa University for reviewing this manuscript.

\section{RESUMO}

Os autores apresentam dois casos de pacientes com linfoma não-Hodgkin, diagnosticados inicialmente como uveite crônica de etiologia não determinada. Os exames posteriores a partir da presença de outros sinais e sintomas demonstraram a presença de linfoma não-Hodgkin nestes pacientes. Um dos pacientes apresentava "flecks" ao nível do epitélio pigmentar da retina e o outro paciente apresentava descolamento sólido do epitélio pigmentar da retina. Estas formas de envolvimento do epitélio pigmentar da retina não são usuais em linfoma nãoHodgkin.

Descritores: Linfoma não-Hodgkin; Uveítes; Síndrome; Neoplasias do sistema nervoso central; Angiofluoresceinografia/ métodos; Epitélio pigmentado ocular; Relatos de casos [tipo de publicação]

\section{REFERENCES}

1. Nussenblatt RB, Whitcup SM. Uveitis: fundamentals and clinical practice, $3^{\text {rd }}$ ed. St. Louis, MO: CV Mosby; 2004. p. 409-19.

2. Theodore FH. Conjunctival carcinoma masquerading as chronic conjunctivitis. Eye Ear Nose Throat Mon. 1967;46(11):1419-20.

3. Irvine AR Jr. Diffuse epibulbar squamous-cell epithelioma. Am J Ophthalmol. 1967;64(3): Suppl:550-4.

4. Gass JD. Stereoscopic atlas of macular diseases: diagnosis and treatment. $4^{\text {th }}$ ed. St. Louis, MO: CV Mosby; 1997.

5. Levy-Clarke GA, Chan CC, Nussenblatt RB. Diagnosis and management of primary intraocular lymphoma. Hematol Oncol Clin North Am. 2005;19(4):739-49.

6. Chan CC, Buggage RR, Nussenblatt RB. Intraocular lymphoma. Curr. Opin Ophthalmol. 2002;13(6):411-8.

7. Behin A, Hoang-Xuan K, Carpentier AF, Delattre JY. Primary brain tumours in adults. Lancet. 2003;361(9354):323-31.

8. Cote TR, Manns A, Hardy CR, Yellin FJ, Hartge P. Epidemiology of brain lymphoma among people with or without acquired immunodeficiency syndrome. AIDS/Cancer Study Group. J Natl Cancer Inst. 1996;88(10):675-9.

9. Corn BW, Marcus SM, Topham A, Hauck W, Curran WJ Jr. Will primary central nervous system lymphoma be the most frequent brain tumor diagnosed in the year 2000? Cancer. 1997;79(12):2409-13.

10. DeAngelis LM, Hormigo A. Treatment of primary central nervous system lymphoma. Semin Oncol. 2004;31(5):684-92.

11. Bataille B, Delwail V, Menet E, Vandermarcq P, Ingrand P, Wager M, et al. Primary intracerebral malignant lymphoma: report of 248 cases. J Neurosurg. 2000;92(2):261-6.

12. Hochberg FH, Miller DC. Primary central nervous system lymphoma. J Neurosurg. 1988;68(6):835-53.

13. Whitcup SM, de Smet MD, Rubin BI, Palestine AG, Martin DF, Burnier M. Jr, et al. Intraocular lymphoma. Clinical and histopathologic diagnosis. Ophthalmology. 1993;100(9):1399-406.

14. Johnson BL. Intraocular and central nervous system lymphoma in a cardiac transplant recipient. Ophthalmology. 1992;99(6):987-92.

15. Schanzer CM, Font RL, O'Malley RE. Primary ocular malignant Lymphoma associated with the acquired immune deficiency syndrome. Ophthalmology. 1991;98(1):88-91.
16. Davis JL, Solomon D, Nussenblatt RB, Palestine AG, Chan CC. Immunocytochemical staining of vitreous cells. Indications, techniques, and results. Ophthalmology. 1992;99(2):250-6.

17. Ljung BM, Char D, Miller TR, Deschenes J. Intraocular lymphoma. Cytologic diagnosis and the role of immunologic markers. Acta Cytol. 1988;32(6):840-7.

18. Whitcup SM, Stark-Vancs V, Wittes RE, Solomon D, Podgor MJ, Nussenblatt RB, et al. Association of interleukin 10 in the vitreous and cerebrospinal fluid and primary central nervous system lymphoma. Arch Ophthalmol. 1997; 115(9):1157-60.

19. Peterson K, Gordon KB, Heinemann MH, DeAngelis LM. The clinical spectrum of ocular lymphoma. Cancer. 1993;72(3):843-9.

20. Margolis L, Fraser R, Lichter A, Char DH. The role of radiation therapy in the management of ocular reticulum cell sarcoma. Cancer. 1980;45(4):688-92.

21. Rouwen AJ, Wijermans PW, Boen-Tan TN, Stilma JS. Intraocular nonHodgkin's lymphoma treated with systemic and intrathecal chemotherapy and radiotherapy. A case report and review of the literature. Graefes Arch Clin Exp. Ophthalmol. 1989;227(4):355-9.

22. Sandor V, Stark-Vancs V, Pearson D, Nussenblat R, Whitcup SM, Brouwers $\mathrm{P}$, et al. Phase II trial of chemotherapy alone for primary CNS and intraocular lymphoma. J Clin Oncol. 1998;16(9):3000-6. Comment in: J Clin Oncol. 1999;17(4):1329.

23. Baumann MA, Ritch PS, Hande KR, Williams GA, Topping TM, Anderson T. Treatment of intraocular lymphoma with high-dose Ara-C. Cancer. 1986; 1;57(7):1273-5.

24. Shapiro WR, Young DF, Mehta BM. Methotrexate: distribution in cerebrospinal fluid after intravenous, ventricular and lumbar injections. N Engl J Med. 1975;293(4):161-6.

25. Fishburne BC, Wilson DJ, Rosenbaum JT, Neuwelt EA. Intravitreal methotrexate as an adjunctive treatment of intraocular lymphoma. Arch Ophthalmol. 1997;115(9):1152-6.

26. De Smet MD. Management of non-Hodkin's intraocular lymphoma with intravitreal methotrexate. Bull Soc Belge Ophthalmol. 2001;(279):91-5.

27. Rothova A, Ooijman F, Kerkhoff F, Van Der Lelij A, Lokhorst HM. Uveitis masquerade syndromes. Ophthalmology. 2001;108(2):386-99. Comment in: Ophthalmology. 2001;108(12):2151-2.

28. Gass JD, Sever RJ, Grizzard WS, Clarkson JG, Blumenkranz M, Wind CA, et al. Multifocal pigment epithelial detachments by reticulum cell sarcoma. A characteristic funduscopic picture. Retina. 1984;4(3):135-43.

29. Wender A, Adar A, Maor E, Yassur Y. Primary B-cell lymphoma of the eyes and brain a 3-year-old boy. Arch Ophthalmol. 1994;112(4):450-1.

30. Givner I. Malignant lymphoma with ocular involvement; a clinico-pathologic report. Am J Ophthalmol. 1990;39(1):29-32.

31. De Smet MD, Nussenblatt RB, Davis JL, Palestine AG. Large cell lymphoma masquerading as a viral retinitis. Int Ophthalmol. 1990;14(5-6):413-7.

32. Gass JDM, Trattler HL. Retinal artery obstruction and atheromas associated with non-Hodgkin's large cell lymphoma (reticulum cell sarcoma). Arch Ophthalmol. 1991;109(8):1134-9.

33. Goder G, Klein S, Konigsdorffer E. [Clinical and pathologic characteristics of malignant lymphoma of the retina] Klin Monatsbl Augenheilkd. 1990; 197(6):514-8. German.

34. Ridley ME, McDonald HR, Sternberg P Jr, Blumenkranz MS, Zarbin MA, Schachat AP. Retinal manifestations of ocular lymphoma (reticulum cell sarcoma). Ophthalmology. 19921;99(7):1153-60; discussion 1160-1.

35. Gray RS, Abrahams JJ, Hufnagel TJ, Kim JH, Lesser RL, Spencer DD. Ghost-cell tumor of the optic chiasm. Primary CNS lymphoma. J Clin Neuroophthalmol. 1989;9(2):98-104.

36. Guyer DR, Green WR, Schachat AP, Bastacky S, Miller NR. Bilateral ischemic optic neuropathy and retinal vascular occlusions associated with lymphoma and sepsis. Clinicopathologic correlation. Ophthalmology. 1990; 97(7):882-8.

37. Kattah JC, Suski ET, Killen JY, Smith FP, Limaye SR. Optic neuritis and systemic lymphoma. Am J Ophthalmol. 1980;89(3):431-6.

38. Lang GK, Surer JL, Green WR, Finkelstein D, Michels RG, Maumenee AE. Ocular reticulum cell sarcoma. Clinicopathologic correlation of a case with multifocal lesions. Retina. 1985;5(2):79-86.

39. Veles G, Chan CC, Csaky KG. Fluorescein angiographic findings in primary intraocular lymphoma. Retina. 2002;22(1):37-43.

40. Augsburger JJ, Correa ZM, Trichopoulos N. Practical clinical classification of intraocular lymphoid tumors and infiltrations [abstract]. Invest Ophthalmol Vis Sci. 2006;47: E-Abstract 2819. 